\title{
Does length of intubation explain the failure of intracuff local anesthetic to reduce postoperative sore throat?
}

\author{
Betul Basaran, MD, DESA (iD · Aysun Ankay Yilbas, MD • Emine Kutahya, MD
}

Received: 4 April 2020/Accepted: 4 April 2020/Published online: 6 May 2020

(C) Canadian Anesthesiologists' Society 2020

\section{To the Editor,}

We read with interest the report by McLachlan et al. ${ }^{1}$ showing neither lidocaine nor ropivacaine reduced the incidence of postoperative sore throat (POST). We are concerned that the low rate of POST in treated and control groups may have left the trial insufficiently powered to identify a treatment effect. Postoperative sore throat rate following general anesthesia has been reported as up to $62 \%,{ }^{2}$ twice that reported by McLachlan et al. Postoperative sore throat has been reported among younger patients, women, those with lung disease, and those undergoing longer surgeries. ${ }^{2}$ McLachlan et al. did not mention the length of anesthesia in their study group. Is it possible that the incidence of POST in their study resulted from relatively short procedures in patients whose average age was in the mid-50s? We believe the final word on the influence of intracuff local anesthetics awaits trials in longer operations among patients at higher risk of POST.
Conflicts of interest None.

Funding statement None.

Editorial responsibility This submission was handled by Dr. Gregory L. Bryson, Deputy Editor-in-Chief, Canadian Journal of Anesthesia.

\section{References}

1. McLachlan M, Gamble J, O’Brien JM, McKay WP, Bajwa JS Intracuff local anesthetic to reduce postoperative sore throat: a randomized clinical trial. Can J Anesth 2020; 67: 495-7.

2. El-Boghdadly $K$, Bailey $C R$, Wiles MD. Postoperative sore throat: a systematic review. Anaesthesia 2016; 71: 706-17.

Publisher's Note Springer Nature remains neutral with regard to jurisdictional claims in published maps and institutional affiliations.

This letter is accompanied by a reply. Please see Can J Anesth 2020; this issue.

B. Basaran, MD, DESA $(\bowtie) \cdot$ E. Kutahya, MD

Department of Anesthesiology, Konya Training and Research Hospital, Konya, Turkey

e-mail: betulbasaran1@yahoo.com

\section{A. Ankay Yilbas, MD}

Department of Anesthesiology and Reanimation, School of Medicine, Hacettepe University, Ankara, Turkey 